\title{
PEMBERDAYAAN MASYARAKAT DALAM PENANGANAN KEGAWATDARURATAN PADA KORBAN BENCANA ALAM DI KABUPATEN GARUT
}

\section{COMMUNITY EMPOWERMENT IN EMERGENCY TREATMENT ON NATURAL DISASTER VICTIMS IN GARUT REGENCY}

\author{
Zahara Farhan $^{1^{*}}$, Devi Ratnasari ${ }^{2}$, Eldessa Vava Rilla ${ }^{3}$ \\ ${ }^{1}$ Program Studi D III Keperawatan STIKes Karsa Husada Garut \\ ${ }^{2}$ Program Studi S-1 Keperawatan STIKes Karsa Husada Garut \\ ${ }^{3}$ Program Studi Profesi Ners STIKes Karsa Husada Garut \\ *E-mail : zaharafarhan585@gmail.com
}

(Diterima 23-08-2021; Disetujui 15-09-2021)

\begin{abstract}
ABSTRAK
Kegiatan penanganan bencana memerlukan adanya sinergitas antara semua pihak baik pemerintah, masyarakat maupun unsur lainnya. Mitra kegiatan ini adalah kader kesehatan dan karang taruna. Permasalahan mitra saat ini adalah; 1) kurangnya kemampuan masyarakat dalam memahami dan meningkatkan keterampilan penanggulangan korban bencana, dan 2) Pemahaman peran keluarga dalam menciptakan metode pengendalian diri agar tidak timbul depresi akibat bencana alam. Sasaran kegiatan ini adalah masyarakat Desa Mangkurakyat Kecamatan Cilawu Kabupaten Garut yang terdampak bencana alam banjir dan tanah longsor. Solusi yang ditawarkan untuk mengatasi permasalahan mitra antara lain; 1) meningkatnya pemahaman dan kemampuan masyarakat dalam melakukan tindakan penanganan kegawatdaruratan pada korban bencana alam, dan 2) meningkatnya pemahaman dan kemampuan masyarakat dalam menangani dampak psikologis akibat bencana alam. Metode pelaksanaan kegiatan ini dilakukan melalui pemberian penyuluhan dan pelatihan tentang penanganan kegawatdaruratan pada korban bencana alam yang dikemas dalam bentuk kegiatan pemberdayaan masyarakat. Kegiatan ini dilaksanakan selama 1 minggu pada bulan Desember 2020 kepada 50 orang peserta. Hasil dari kegiatan ini hampir seluruh peserta (82\%) memiliki tingkat pengetahuan baik dan hampir seluruh peserta (94\%) mampu melakukan penanganan kegawatdaruratan pada korban bencana alam setelah dilakukan kegiatan. Keberhasilan dari kegiatan ini dipengaruhi oleh kuatnya partisipasi masyarakat dalam pelaksanaan kegiatan, dimana tingginya masyarakat untuk ingin tahu terhadap informasi dan tingginya kemauan masyarakat untuk mengikuti kegiatan ini. Kegiatan pemberdayaan masyarakat ini mampu meningkatkan tingkat pengetahuan dan kemampuan masyarakat dalam menangani kegawatdaruratan pada korban bencana alam. Kegiatan pemberdayaan masyarakat ini dapat dijadikan salah satu alternatif untuk membantu pemerintah daerah dalam melaksanakan program penanggulangan bencana alam di Kabupaten Garut.
\end{abstract}

Kata Kunci : Penanganan Kegawatdaruratan, Bencana Alam, Masyarakat

\section{ABSTRACT}

Disaster management activities require synergy between all parties, including the government, the community and other elements. Partners of this activity are health cadres and youth organizations. Current partner problems are; 1). lack of community capacity in understanding and improving disaster victim management skills, 2). Understanding the role of the family in creating self-control methods so that depression does not arise due to natural disasters. The target of this activity is the community of Mangkurakyat Village, Cilawu District, Garut Regency which is affected by floods and landslides. The solutions offered to overcome partner problems include; 1). increasing the understanding and ability of the community in carrying out emergency treatment for victims of natural disasters, 2). increasing the understanding and ability of the community in dealing with the psychological impacts of natural disasters. The method of implementing this activity is through the provision of counseling and training on emergency treatment for victims of natural disasters which are packaged in the form of community empowerment activities. This activity was carried out for 1 week in December 2020 for 50 participants. The result of this activity is that almost all participants (82\%) have a good level of knowledge and almost all participants (94\%) are able to treatment emergency situations for victims of natural disasters after the activity. The success of this activity is influenced by the strong community participation in the implementation of the activity, where the community is high to want to know about information and the high willingness of the 
community to take part in this activity. This community empowerment activity is able to increase the level of knowledge and ability of the community in treatment emergencies for victims of natural disasters. This community empowerment activity can be used as an alternative to assist local governments in implementing natural disaster management programs in Garut Regency.

Keywords: Emergency Management, Natural Disasters, Society

\section{PENDAHULUAN}

Kejadian bencana alam di Indonesia selama tahun 2019 mulai dari 1 Januari 2019 sampai 23 Desember 2019 terdapat 3.721 kejadian bencana alam (Badan Nasional Penanggulangan Bencana, 2019). Berdasarkan data Badan Penanggulangan Bencana Daerah Provinsi Jawa Barat, selama Januari hingga November 2019 terjadi 1.740 kejadian bencana alam, terdiri atas; 478 tanah longsor, 385 kebakaran hutan dan lahan, 368 puting beliung, 138 banjir, dan 14 gempa bumi (Huyogo, 2019). Berdasarkan data Badan Pusat Statistik Kabupaten Garut, selama tahun 2017 telah terjadi 220 kejadian bencana alam yang terdiri atas; 10 banjir, 131 kebakaran, 41 tanah longsor, 27 puting beliung, dan 11 gempa bumi. Kecamatan Cilawu merupakan wilayah yang sering terkena bencana, pada tahun 2017 mengalami bencana alam sebanyak 1 kali banjir, 1 kali kebakaran, dan 6 kali longsor (Badan Pusat Statistik Kabupaten Garut, 2018).

Dampak yang dapat ditimbulkan bencana alam pada aspek fisik berupa badan cepat lelah, terasa tegang, nafsu makan menurun, susah tidur, patah tulang, luka-luka, dan meningkatnya kejadian penyakit menular ataupun tidak menular seperti; malaria, demam berdarah, diare, gatal-gatal, infeksi kulit ataupun masalah lain akibat kerusakan sistem sanitasi dan air bersih sehingga menimbulkan potensi kejadian luar biasa (KLB) penyakit yang ditularkan melalui media air atau lingkungan (Rusmiyati \& Hikmawati, 2012).

Dampak psikologis juga merupakan salah satu masalah utama akibat bencana. Terjadinya stres pasca bencana, trauma, kecemasan, dan depresi merupakan dampak psikologis akibat bencana sebagai peristiwa traumatik yang sangat berat. Menurut (Fullerton et al., 2010), mayoritas orang yang terkena bencana akan mengalami reaksi kejiwaan berupa respon kehilangan (loss), stres, dan trauma yang mempengaruhi behavioral outcome. Hal ini sejalan dengan pendapat yang dikemukakan oleh (Hayatul Khairul Rahmat, 2018) yang mengemukakan bahwa, dampak psikologis akibat bencana dapat dipengaruhi oleh perubahan interaksi atau gangguan fisik, psikologi, situasi sosial, dan masalah yang bersifat material. Oleh karena itu, diperlukan suatu solusi untuk mengurangi dampak psikologis pada korban bencana. 
Dampak bencana terhadap aspek sosial berhubungan dengan kematian, perpisahan, dan kehilangan (kehilangan status sosial, posisi serta peran dalam masyarakat), kerusakan nilai-nilai sosial dan rusaknya fasilitas serta terganggunya institusi yang bertanggung jawab memelihara modal sosial (Mundakir, 2011). Hal ini sejalan dengan hasil penelitian yang dilakukan (Irzalinda, Vivi, dan Sofia, 2019) yang menjelaskan bahwa, dampak sosial yang ditimbulkan akibat bencana dapat mengakibatkan tercerai berainya masyarakat, rusaknya nilai-nilai kekeluargaan, dan hancurnya tatanan masyarakat.

Kejadian bencana juga dapat berdampak terhadap aktifitas spiritual seseorang. Respon yang dilakukan oleh individu atau masyarakat ada yang meyakini bahwa apa yang terjadi merupakan kehendak sang pencipta sehingga akan melakukan kegiatan-kegiatan spiritualnya dengan cara berdo'a, atau melakukan kegiatan peribadatan lainnya untuk mendekatkan diri kepada Tuhan. Namun, ada juga individu atau masyarakat yang menampilkan respon yang berbeda yaitu dengan menyesali kejadian bencana alam yang terjadi atau bahkan menyalahkan kuasa Tuhan yang membuat mereka putus asa dan tidak melakukan kegiatan-kegiatan peribadatan (Milstein, 2019).

Tingginya kejadian bencana yang ada di hampir seluruh wilayah Indonensia memerlukan perhatian dan penanganan yang serius dari pemerintah. Kegiatan penanggulangan kebencanaan yang selama ini dilakukan meliputi berbagai tahap, mulai dari edukasi, kesiapsiagaan, mitigasi, respon tanggap darurat bencana sampai dengan tahap pemulihan (recovery). Kegiatan penangangan bencana tidak hanya menjadi tanggungjawab pemerintah, tetapi memerlukan adanya sinergitas antara semua pihak baik masyarakat maupun unsur lainnya, hal tersebut dikarenakan upaya kesiapsiagaan dalam menghadapi bencana sangat diperlukan oleh seluruh pemangku kebijakan terutama masyarakat yang berada di wilayah dengan potensi bencana yang tinggi (Ulum, 2013).

Desa Mangkurakyat Kecamatan Cilawu Kabupaten Garut berada di antara wilayah Gunung Cikuray dan Daerah Aliran Sungai (DAS) Cimanuk yang merupakan salah satu daerah dengan potensi bencana yang tinggi dimana hampir setiap tahun mengalami bencana banjir bandang dan tanah longsor. Kejadian banjir bandang yang terjadi di daerah tersebut sudah terjadi selama bertahun-tahun terutama setiap kali turun hujan. Berdasarkan hasil wawancara dengan beberapa tokoh masyarakat dan tokoh agama di desa tersebut didapatkan data bahwa dampak yang terjadi pada masyarakat setelah mengalami bencana tersebut yaitu mengalami penurunan aktifitas mulai dari aktifitas spiritual, sosial, dan kesehatan. Faktor-faktor tersebut dikarenakan kejadian bencana alam menimbulkan ketakutan atau trauma, kecemasan, konflik, juga mengalami ketegangan psikologi. 
Masyarakat mengalami perubahan emosi, terjadinya berbagai penyakit dan penurunan aktifitas spiritual. Jika kondisi tersebut tidak diatasi maka akan menimbulkan stres pada setiap individu.

Kegiatan penanggulangan bencana yang sudah berjalan di daerah tersebut lebih banyak dilakukan oleh pemerintah daerah melalui Badan Penanggulangan Bencana Daerah (BPBD) sehingga kurang membangkitkan partisipasi masyarakat untuk mengatasi munculnya kerawanan sosial. Hal tersebut lebih disebabkan oleh struktur sosial masyarakat setempat yang rata-rata kaum urban, khususnya laki-laki yang rata-rata bekerja di luar daerah. Kelompok sosial yang memungkinkan dapat menyentuh langsung kepada masyarakat dalam kegiatan penanggulangan bencana adalah kelompok masyarakat yang khusus dalam menangani bencana (kelompok siaga bencana). Sampai saat ini di Desa Mangkurakyat Kecamatan Cilawu Kabupaten Garut belum memiliki kader siaga bencana yang khusus menangani atau konsentrasi untuk menangani dampak yang muncul akibat bencana. Keberadaan kelompok masyarakat tersebut dapat dijadikan sebagai peluang untuk menjadi kelompok siaga bencana serta menjadi media penghubung dengan masyarakat dalam menginformasikan kegiatan penanggulangan bencana. Pengetahuan dan kemampuan masyarakat dalam penanganan bencanaan terutama dalam mitigasi bencana, penanganan korban bencana, dan rehabilitasi pasca bencana masih sangat kurang sehingga perlu dilakukan pembinaan dan pendampingan secara intensif. Kegiatan penanganan bencana ini merupakan tahapan yang sangat penting sebagai tindak lanjut dalam meningkatkan kapasitas masyarakat untuk menumbuhkan semangat agar dapat bangkit dan mencegah terjadinya bencana termasuk meminimalisir dampak dari bencana yang terjadi.

Berdasarkan hasil komunikasi dengan kelompok mitra pada kegiatan ini disepakati beberapa permasalahan yang muncul terkait dengan mitigasi dan penanggulangan bencana alam terutama dalam aspek penanganan masalah kesehatan, dan peningkatan kemandirian rehabilitasi dan recovery pasca terjadinya bencana sebagai berikut:

1. Kurangnya kemampuan masyarakat dalam memahami dan meningkatkan keterampilan penanggulangan korban bencana.

2. Pemahaman peran keluarga dalam menciptakan metode pengendalian diri agar tidak timbul depresi akibat bencana alam.

Berdasarkan permasalahan tersebut diatas, maka tujuan/target luaran yang akan ingin dicapai untuk mengatasi permasalahan tersebut antara lain; 1) meningkatnya pemahaman dan kemampuan masyarakat dalam melakukan tindakan penanganan kegawatdaruratan 
pada korban bencana alam, dan 2) meningkatnya pemahaman dan kemampuan masyarakat dalam menangani dampak trauma psikologis akibat bencana alam.

Hasil dari kegiatan ini masyarakat dapat mengetahui, memahami dan mendapatkan keterampilan dalam upaya menanganai kegawatdaruratan pada korban bencana alam. Selain itu, kelompok masyarakat yang telah diberikan pelatihan dan pendampingan dapat mentransferkan pengetahuan dan keterampilan yang dikuasainya kepada masyarakat lainnya. Disamping itu, kelompok masyarakat tersebut dapat ikut serta dalam kegiatan inovasi pengembangan program daerah terutama di tingkat desa dalam bidang kesehatan dan kebencanaan yang diselenggarakan oleh pemerintah daerah Kabupaten Garut.

\section{BAHAN DAN METODE}

Kegiatan pengabdian kepada masyarakat ini dilaksanakan dalam bentuk program kemitraan masyarakat stimulus (PKMS) melalui metode pemberdayaan masyarakat yang dilaksanakan melalui tahapan sebagai berikut:

1. Tahap Persiapan

a. Menyusun Materi dan Modul Kegiatan

Sebelum kegiatan dilaksanakan, tim pelaksana menyusun bahan yang akan digunakan berupa materi, modul, dan jadwal kegiatan yang akan dilaksanakan.

b. Melakukan Perkenalan dengan Kepala Desa dan Kelompok Masyarakat

Pelaksanaan kegiatan pengabdian masyarakat diawali dengan kegiatan pertemuan dengan para pamong Desa, tokoh masyarakat, tokoh agama, karang taruna, dan kelompok kader masyarakat yang ada di wilayah Desa Mangkurakyat untuk menyampaikan maksud dan rencana kegiatan yang akan dilaksanakan.

c. Mengurus Perijinan Kegiatan

Tim pelaksana selanjutnya melakukan pengurusan perijinan dengan pemerintah kecamatan dan desa setempat sekaligus meminta dukungan dari semua pihak untuk keberlangsungan dan kelancaran kegiatan tersebut.

2. Tahap Perencanaan

a. Identifikasi Potensi dan Permasalahan

Tim pelaksana kegiatan melakukan wawancara dengan kelompok masyarakat (tokoh masyarakat, karang taruna, dan kader) untuk mengumpulkan informasi awal dan mengidentifikasi permasalahan yang terkait dengan penanganan kegawatdaruratan pada korban bencana alam. Kegiatan dilanjutkan dengan 
melakukan survey ke lokasi yang memiliki tingkat kerawanan tinggi terhadap bencana alam didampingi oleh para kader dan karang taruna wilayah setempat.

b. Persamaan Persepsi Kegiatan

Tim pelaksana kegiatan melakukan pertemuan khusus dengan kelompok-kelompok yang akan dijadikan sebagai mitra kegiatan untuk menjelaskan dan memahami langkah-langkah dan tujuan yang akan dicapai. Hal ini dilakukan supaya proses pelaksanaan kegiatan lebih terorganisir dan difahami oleh semua pihak sehingga maksud tujuan kegiatan dapat tercapai dengan baik.

\section{Tahap Pelaksanaan}

a. Melakukan Pengukuran Tingkat Pengetahuan Kelompok Mitra Tentang Pencegahan dan Penanganan Bencana

Tim pelaksana melakukan kegiatan pre test untuk mengetahui tingkat pengetahuan dan pemahaman kelompok mitra tentang penanganan kegawatdaruratan pada korban bencana alam sebelum dilakukan kegiatan. Hal ini dilakukan sebagai dasar bagi tim pelaksana untuk menentukan teknik dan pola pelaksanaan kegiatan yang akan dilakukan kepada kelompok mitra. Pengukuran tingkat pengetahuan tersebut menggunakan kuesioner yang berisi tentang pertanyaan yang terkait dengan topik kegiatan.

b. Membagikan Jadwal, Panduan Kegiatan, dan Booklet Kepada Peserta

Tim pelaksana membagikan jadwal, panduan, dan booklet kepada para peserta untuk dipelajari dan difahami sebagai pedoman selama kegiatan dan setelah berlangsung.

c. Melakukan Penyuluhan Penanganan Kegawatdaruratan pada Korban Bencana Alam Tim pelaksana kegiatan melakukan penyuluhan kepada kelompok kader dan karang taruna sebagai mitra kerjasama tentang penanganan kegawatdaruratan pada korban bencana alam. Upaya ini dilakukan melalui proses peningkatan pengetahuan dan pemahaman masyarakat dalam mengidentifikasi, menganalisa, dan menilai berbagai kemungkinan yang terjadi serta meminimalisir munculnya kegawatdaruratan lanjut pada korban bencana alam.

d. Melakukan Demonstrasi dan Pelatihan Penanganan Kegawatdaruratan pada Korban Bencana Alam

Tim pelaksana kegiatan melakukan demonstrasi tentang penanganan kegawatdaruratan pada korban bencana alam termasuk tindakan-tindakan penanganan awal dalam menangani korban sebelum ditangani oleh tim medis. Hal 
ini dilakukan supaya masyarakat mampu mengenal dan memahami tindakan awal yang harus dilakukan untuk mengurangi jatuhnya korban jiwa yang lebih banyak. Tindakan penanganan yang didemonstrasikan berupa tindakan bantuan hidup dasar (basic life support), tindakan evakuasi dan pemindahan korban ke tempat pengungsian, tindakan penanganan luka dan perdarahan akibat trauma, serta tindakan perawatan kesehatan di tempat pengungsian.

e. Melakukan Simulasi Konseling Kesehatan Mental

Tim pelaksana kegiatan mempraktikan teknik konseling kepada kelompok mitra melalui wawancara yang mendalam (indepth interview) kepada korban bencana alam terkait dengan keluhan-keluhan yang mereka rasakan pada aspek psikologis. Hal ini dilakukan supaya kelompok mitra mampu mengidentifikasi, menangani dan melakukan upaya rujukan terhadap permasalahan psikologis yang muncul pada korban bencana alam.

f. Melakukan Pembentukan Kelompok Siaga Bencana.

Tim pelaksana kegiatan bersama kelompok mitra membentuk kelompok masyarakat siaga bencana di Desa Mangkurakyat Kecamatan Cilawu sebagai garda terdepan dalam menangani bencana alam. Selain itu, tim pelaksana dan kelompok mitra membuat sistem jejaring informasi di tingkat desa melalui pembuatan call center Pusat Informasi Bencana Desa Mangkurakyat dan pembuatan grup whatsapp kelompok siaga bencana desa yang beranggotakan masing-masing anggota kelompok siaga bencana setiap dusun yang ada di wilayah Desa Mangkurakyat.

4. Tahap Evaluasi

Tim pelaksana melakukan kegiatan post test untuk mengetahui tingkat pengetahuan dan pemahaman kelompok mitra tentang pencegahan dan penanganan bencana sebelum dilakukan kegiatan. Selain itu, tim pelaksana juga meminta kelompok mitra untuk mendemonstrasikan ulang tindakan-tindakan penanganan kegawatdaruratan dalam menangani korban bencana alam seperti; tindakan bantuan hidup dasar (basic life support), tindakan evakuasi dan pemindahan korban ke tempat pengungsian, tindakan penanganan luka dan perdarahan akibat trauma, serta tindakan perawatan kesehatan di tempat pengungsian. Pengukuran pengetahuan kelompok mitra dilakukan menggunakan kuesioner, sedangkan pengukuran kemampuan soft skill tindakan menggunakan lembar ceklist observasi. 


\section{HASIL DAN PEMBAHASAN}

Kegiatan pemberdayaan masyarakat dilakukan selama 1 minggu di aula Desa Mangkurakyat pada bulan Desember tahun 2020. Pelaksanaan kegiatan dihadiri oleh para tokoh masyarakat, karang taruna, anggota satuan tugas siaga bencana tingkat kecamatan, tokoh agama dan petugas puskesmas setempat. Kegiatan diikuti oleh 50 peserta dan dibuka oleh camat Cilawu. Setelah kegiatan pembukaan, selanjutnya tim pelaksana melakukan pre test untuk mengetahui tingkat pengetahuan peserta terhadap topik kegiatan yang akan dilaksanakan untuk selanjutnya dilaksanakan kegiatan pemaparan materi kegiatan oleh tim pelaksana pengabdian masyarakat.

Kegiatan pemaparan materi dilakukan selama 2 hari, selanjutnya peserta dibagi menjadi 5 kelompok untuk dilakukan demonstrasi penanganan kegawatdaruratan pada korban bencana alam termasuk tindakan-tindakan penanganan awal dalam menangani korban sebelum ditangani oleh tim medis. Kegiatan demonstrasi ini dilaksanakan selama 2 hari dan didampingi oleh tim pelaksana kegiatan. Setelah kegiatan demonstrasi, selanjutnya tim pelaksana kegiatan membuka kegiatan konseling selama 1 hari kepada para korban yang terdampak bencana dengan melibatkan peserta sekaligus mempraktikan teknik konseling melalui metode wawancara mendalam (indepth interview). Selanjutnya peserta diberikan kesempatan untuk mempraktikan teknik konseling tersebut kepada korban bencana alam dengan didampingi oleh tim pelaksana kegiatan.

Kegiatan selanjutnya tim pelaksana kegiatan bersama para peserta kegiatan membentuk tim satuan siaga bencana desa yang terbagi menjadi 5 kelompok dimana 1 kelompok beranggotakan 10 orang. Kelompok tersebut dibentuk sesuai dengan jumlah dusun yang ada di Desa Mangkurakyat yaitu sebanyak 5 dusun. Pembentukan kelompok siaga bencana tersebut dihadiri oleh kepala desa, tokoh masyarakat, tokoh agama, karang taruna, dan kepala kantor Kecamatan Cilawu sekaligus disahkan oleh camat Cilawu. Setelah pembentukan satuan siaga bencana desa, pada hari terakhir (hari ke enam) tim pelaksana kegiatan melakukan post test baik untuk mengukur pengetahuan peserta maupun untuk mengukur keterampilan dan kemampuan peserta dalam melakukan penanganan kegawatdaruratan pada korban bencana alam termasuk tindakan-tindakan penanganan awal dalam menangani korban sebelum ditangani oleh tim medis dengan meminta para peserta mendemonstrasikan seluruh tindakan/kegiatan yang telah dipraktikan oleh tim pelaksana selama kegiatan berlangsung. Pengukuran evaluasi kegiatan (post test) untuk aspek pengetahuan dan sikap menggunakan kuesioner, sedangkan untuk pengukuran aspek keterampilan menggunakan lembar ceklist observasi. 

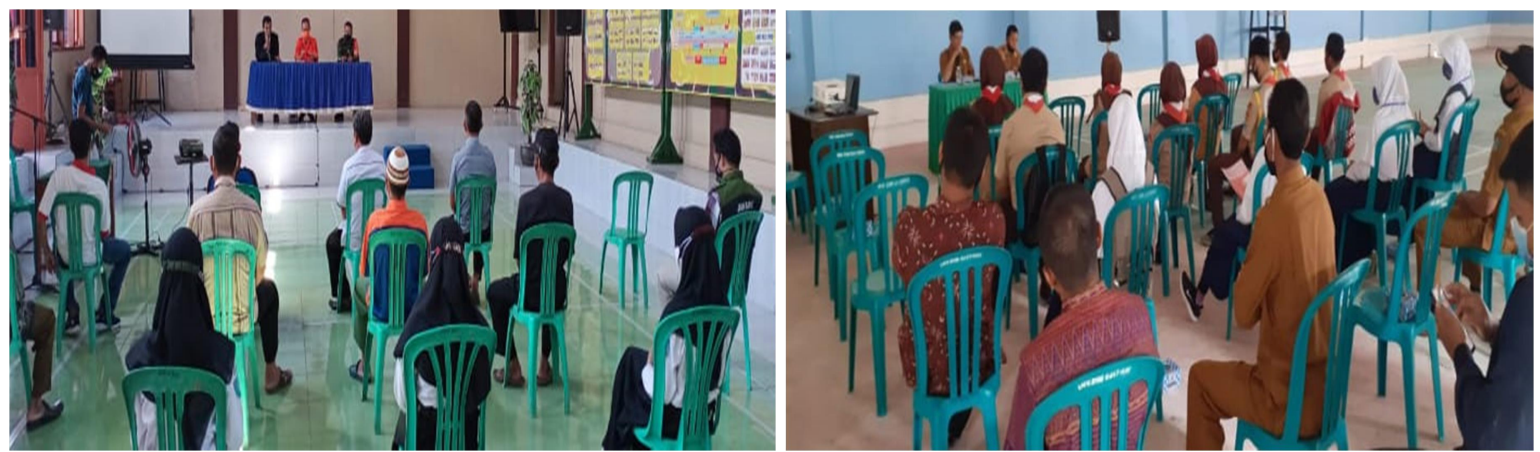

Gambar 1. Kegiatan Penyuluhan Penanganan Kegawatdaruratan pada Korban Bencana Alam
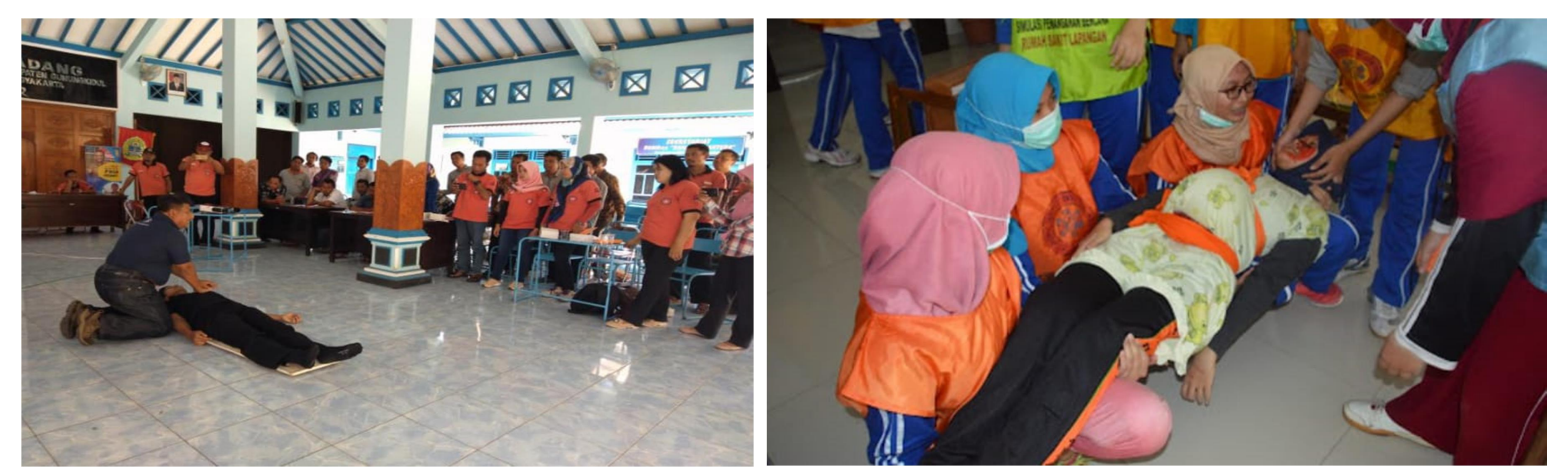

Gambar 2. Kegiatan Pelatihan dan Demonstrasi Penanganan Kegawatdaruratan pada Korban Bencana Alam

Hasil pelaksanaan kegiatan pemberdayaan masyarakat dalam penanganan kegawatdaruratan pada korban bencana alam di Kabupaten Garut secara keseluruhan dapat dilihat pada Tabel 1 .

\section{Karakteristik Peserta Kegiatan}

Karakteristik peserta kegiatan pemberdayaan masyarakat tentang penanganan kegawatdaruratan pada korban bencana alam di Kabupaten Garut dapat dilihat pada Tabel 1 .

Berdasarkan Tabel 1 diketahui bahwa, sebagian besar (58\%) peserta kegiatan berjenis kelamin laki-laki, sebagian besar (52\%) memiliki pekerjaan buruh, hampir seluruhnya (68\%) memiliki tingkat pendidikan SMA/MA, dan hampir seluruhnya (74\%) berada pada usia produktif yaitu berada pada rentang usia 18-45 tahun. Kondisi tersebut merupakan salah satu potensi yang dimiliki oleh masyarakat untuk meningkatkan peran sertanya dalam menghadapi dan menangani segala permasalahan yang muncul akibat bencana sehingga memudahkan tim pelaksana kegiatan dalam melakukan pemberdayaan kepada masyarakat tentang penanggulangan dampak bencana alam. 


\begin{tabular}{clcc}
\hline No & \multicolumn{1}{c}{ Karakteristik Peserta } & f & \% \\
\hline $\mathbf{1}$ & Jenis Kelamin & & \\
& a. Laki - Laki & 29 & 58 \\
& b. Perempuan & 21 & 42 \\
\hline $\mathbf{2}$ & Pekerjaan & & \\
& a. PNS & 2 & 4 \\
& b. Swasta & 9 & 18 \\
& c. Wiraswasta & 8 & 16 \\
& d. Buruh & 26 & 52 \\
& e. Tidak Bekerja & 5 & 10 \\
\hline 3 Pendidikan & & \\
& a. Tidak Sekolah & 0 & 0 \\
& b. SD / SR & 2 & 4 \\
& c. SMP / MTs & 2 & 4 \\
& d. SMA / MA & 34 & 68 \\
& e. D III & 5 & 10 \\
& f. Sarjana & 7 & 14 \\
\hline $\mathbf{4}$ & Umur & & \\
& a. $18-45$ tahun & 37 & 74 \\
& b. 46 - 55 tahun & 9 & 18 \\
& c. 56 - 65 tahun & 4 & 8 \\
d. $>$ 65 tahun & 0 & 0 \\
\hline
\end{tabular}

\section{Tingkat Pengetahuan Peserta Sebelum dan Sesudah Kegiatan}

Tingkat pengetahuan peserta kegiatan pemberdayaan masyarakat tentang penanganan kegawatdaruratan pada korban bencana alam di Kabupaten Garut dapat dilihat pada Tabel 2.

Tabel 2. Tingkat Pengetahuan Peserta Kegiatan $(n=50)$

\begin{tabular}{lccccc}
\hline \multirow{2}{*}{ Tingkat Pengetahuan Peserta } & \multicolumn{2}{c}{ Sebelum Kegiatan } & \multicolumn{2}{c}{ Sebelum Kegiatan } \\
\cline { 2 - 5 } & f & \% & f & \% \\
\hline a. Baik & 3 & 6 & 41 & 82 \\
b. Cukup & 9 & 18 & 9 & 18 \\
c. Kurang & 38 & 76 & 0 & 0 \\
\hline
\end{tabular}

Berdasarkan Tabel 2 diketahui bahwa, hampir seluruh peserta (76\%) memiliki tingkat pengetahuan kurang sebelum dilakukan kegiatan dan hampir seluruh peserta $(82 \%)$ memiliki tingkat pengetahuan baik setelah dilakukan kegiatan tentang penanganan kegawatdaruratan pada korban bencana alam di Kampung Warung Cagak Desa Mangkurakyat Kecamatan Cilawu Kabupaten Garut.

Adanya perubahan tingkat pengetahuan peserta dipengaruhi oleh tingat pendidikan yang dimiliki oleh peserta, dimana tingkat pendidikan seseorang akan mempengaruhi pemahaman terhadap suatu informasi. Berdasarkan data pada Tabel 1 menunjukan, hampir seluruh peserta memiliki tingkat pendidikan SMA/MA dan sebagian kecil lainnya memiliki tingkat pendidikan diploma III dan sarjana. Menurut (Sukmadinata, 2013), tingkat pendidikan seseorang akan berpengaruh dalam berespon yang lebih rasional terhadap suatu 
informasi dan akan berfikir sejauhmana keuntungan yang mungkin akan mereka peroleh dari suatu gagasan. Dalam konteks kegiatan pemberdayaan masyarakat ini, peserta diberikan penyuluhan dan pelatihan berupa demonstrasi dari suatu tindakan sebagai bekal ilmu pengetahuan bagi mereka dalam upaya penanggulangan bencana alam yang sering terjadi di daerahnya sehingga tingkat pengetahuan mereka tentang upaya-upaya penanggulangan bencana meningkat.

\section{Tingkat Kemampuan Peserta Sebelum dan Sesudah Kegiatan}

Tingkat kemampuan peserta kegiatan pemberdayaan masyarakat tentang penanganan kegawatdaruratan pada korban bencana alam di Kabupaten Garut dapat dilihat pada Tabel 3.

Tabel 3. Tingkat Kemampuan Peserta Kegiatan $(n=50)$

\begin{tabular}{lcccc}
\hline \multirow{2}{*}{ Tingkat Kemampuan Peserta } & \multicolumn{2}{c}{ Sebelum Kegiatan } & \multicolumn{2}{c}{ Sebelum Kegiatan } \\
\cline { 2 - 5 } & $\mathbf{f}$ & $\mathbf{\%}$ & $\mathbf{f}$ & $\mathbf{\%}$ \\
\hline a. Mampu & 0 & 0 & 47 & 94 \\
b. Kurang Mampu & 7 & 14 & 3 & 6 \\
c. Tidak Mampu & 43 & 86 & 0 & 0 \\
\hline
\end{tabular}

Berdasarkan Tabel 3 diketahui bahwa, hampir seluruh peserta (86\%) tidak mampu sebelum dilakukan kegiatan dan hampir seluruh peserta (94\%) mampu setelah dilakukan kegiatan penanganan kegawatdaruratan pada korban bencana alam di Kampung Warung Cagak Desa Mangkurakyat Kecamatan Cilawu Kabupaten Garut.

Adanya perubahan tingkat kemampuan peserta setelah dilakukan kegiatan pelatihan/demonstrasi tentang upaya penanganan kegawatdaruratan pada korban bencana termasuk tindakan-tindakan penanganan awal dalam menangani korban bencana alam sebelum ditangani oleh tim medis. Selama 2 hari peserta diberikan pelatihan dengan cara mendemonstrasikan tindakan-tindakan penanganan kegawatdaruratan seperti; tindakan penanganan yang didemonstrasikan berupa tindakan bantuan hidup dasar (basic life support), tindakan evakuasi dan pemindahan korban ke tempat pengungsian, tindakan penanganan luka dan perdarahan akibat trauma, serta tindakan perawatan kesehatan di tempat pengungsian.

Upaya/solusi yang ditawarkan tersebut bertujuan untuk menciptakan dan mengembangkan kapasitas dan pemberdayaan masyarakat di wilayah rawan bencana melalui optimalisasi peran dan fungsi kelompok masyarakat siaga bencana di Desa Mangkurakyat dengan harapan memberikan dampak berupa perubahan sikap dan peningkatan keterampilan masyarakat melalui pendidikan, pelatihan, pembinaan, dan pendampingan yang telah diberikan oleh tim pelaksana kegiatan. Hal tersebut sebagai bekal bagi masyarakat dalam mengatasi berbagai permasalahan yang timbul akibat 
bencana. Hal ini sejalan dengan hasil penelitian yang dilakukan oleh (Mundakir, 2011) yang mengungkapkan bahwa, upaya pemberdayaan kepada masyarakat yang terdampak bencana merupakan salah satu bentuk alternatif pemecahan masalah dalam menghadapi atau merespon berbagai stresor yang ada akibat bencana untuk mengalihkan perhatian agar dapat menurunkan ketegangan social yang terjadi di masyarakat. Pendapat yang sama dikemukakan oleh (Ballesteros et al., 2014) yang mengemukakan bahwa, kegiatan pelatihan yang diberikan kepada orang dewasa cenderung dapat meningkatkan tingkat kemampuan individu atau masyarakat dalam upaya memecahkan permasalahan yang muncul di kehidupan masyarakat. Hal tersebut juga didukung oleh hasil penelitian yang dilakukan oleh (Rusmiyati \& Hikmawati, 2012) yang mengungkapkan bahwa, dampak yang ditimbulkan pasca bencana alam memerlukan kemampuan pribadi maupun lingkungan sebagai sumber daya yang diperlukan untuk mengurangi dan menangani dalam menghadapi segala kesulitan serta mengendalikan segala sesuatu yang dapat mengancam individu atau masyarakat.

Berdasarkan hasil evaluasi kegiatan, adanya keberhasilan dari kegiatan yang telah dilakukan dipengaruhi oleh kuatnya partisipasi dan keterlibatan masyarakat dalam pelaksanaan kegiatan ini, dimana tingginya masyarakat untuk ingin tahu terhadap informasi yang diberikan oleh tim pelaksana dan tingginya kemauan masyarakat untuk mengikuti kegiatan ini. Hal ini terbukti dari kesediaan masyarakat dalam penyediaan tempat penyuluhan dan pelatihan, penyediaan area simulasi penanganan kegawatdaruratan pada korban bencana alam sampai dengan mengurusi perizinan untuk pelaksanaan kegiatan yang ditembuskan ke pemerintah Desa Mangkurakyat dan pemerintahan Kecamatan Cilawu. Di samping itu, juga masyarakat secara sukarela menyediakan kebutuhan dan peralatan teknis yang dibutuhkan untuk pelaksanaan demonstrasi dalam tindakan pertolongan kegawatdaruratan. Partisipasi masyarakat dalam penyediaan sarana dan prasarana untuk pelaksanaan disediakan oleh masyarakat sendiri (menggunakan kepunyaan masing-masing peserta) hal ini mempermudah mereka dalam proses pemahaman materi dan keterampilan yang akan mereka dapatkan.

\section{KESIMPULAN DAN SARAN}

Kegiatan pemberdayaan masyarakat dalam penanganan kegawatdaruratan pada korban bencana alam di Desa Mangkurakyat Kecamatan Cilawu mampu meningkatkan tingkat pengetahuan dan kemampuan masyarakat dalam menangani kegawatdaruratan pada korban bencana alam. Kegiatan pemberdayaan masyarakat ini juga telah berhasil dalam 
membentuk kelompok satuan siaga bencana di tingkat desa yang terbagi ke dalam 5 kelompok satuan siaga bencana pada tingkat dusun.

Kegiatan pemberdayaan masyarakat ini dapat dijadikan sebagai salah satu alternatif untuk membantu pemerintah daerah dalam melaksanakan program penanggulangan bencana alam di Kabupaten Garut.

\section{DAFTAR PUSTAKA}

Badan Nasional Penanggulangan Bencana. (2019). Kejadian Bencana Tahun 2019. In Badan Nasional Penanggulangan Bencana. https://bnpb.go.id/infografis/kejadianbencana-tahun-2019.

Badan Pusat Statistik Kabupaten Garut. (2018). Jumlah Bencana Alam Menurut Jenis Bencana di Kabupaten Garut 2017. https://garutkab.bps.go.id/statictable/2018/04/12/313/jumlah-bencana-alam-menurutjenis-bencana-di-kabupaten-garut-tahun-2017.html.

Ballesteros, S., Prieto, A., Mayas, J., Toril, P., Pita, C., de León, L. P., Reales, J. M., \& Waterworth, J. (2014). Brain training with non-action video games enhances aspects of cognition in older adults: A randomized controlled trial. Frontiers in Aging Neuroscience, 6(OCT), 1-14. https://doi.org/10.3389/fnagi.2014.00277.

Fullerton, C. S., Reissman, D. B., Gray, C., Flynn, B. W., \& Ursano, R. J. (2010). Earthquake response and psychosocial health outcomes: Applying lessons from integrating systems of care and recovery to Haiti. In Disaster Medicine and Public Health Preparedness (Vol. 4, Issue 1, pp. 15-17). Cambridge University Press. https://doi.org/10.1017/S1935789300002354

Hayatul Khairul Rahmat. (2018). Traumatic Counseling Services as an Effort to Improve Resilience of Natural Disaster Victims. Department of Islamic Guidance and Counseling of State Islamic University of Sunan Kalijaga. http://conference.uinsuka.ac.id/index.php/icigc/article/view/246

Huyogo, S. (2019). Deretan Bencana Alam di Jabar Sepanjang Januari-November 2019. https://www.liputan6.com/regional/read/4125804/deretan-bencana-alam-di-jabarsepanjang-januari-november-2019

Irzalinda, Vivi , dan Sofia, A. (2019). Pengaruh Koping Strategi terhadap Resilience Keluarga Rawan Bencana. Jurnal Obsesi : Jurnal Pendidikan Anak Usia Dini, 4(1), 201-210. https://doi.org/10.31004/obsesi.v4i1.312

Milstein, G. (2019). Disasters, psychological traumas, and religions: Resiliencies examined. In Psychological Trauma: Theory,Research, Practice and Policy (Vol. 11, Issue 6, pp. 559-562). Educational Publishing Foundation of the American Psychological Association). https://doi.org/10.1037/tra0000510

Mundakir, S. (2011). Dampak Psikososial Akibat Bencana Lumpur Lapindo (Psychosocial Impact of Lapindo Mud Disaster). Jurnal Ners, 6(1), 42-49. https://www.ejournal.unair.ac.id/JNERS/article/view/3964.

Rusmiyati, C., \& Hikmawati, E. (2012). Penanganan Dampak Sosial Psikologis Korban Bencana Merapi (Sosial Impact of Psychological Treatment Merapi Disaster Victims). Jurnal Informasi, 17(02), 97-110. http://ejournal.kemensos.go.id/index.php/Sosioinforma/article/viewFile/96/64

Sukmadinata, N. S. (2013). Metode Penelitian Pendidikan (1st ed.). PT Remaja Rosda Karya. Bandung. 
Ulum, M. C. (2013). Governance Dan Capacity Building Dalam Manajemen Bencana Banjir Di Indonesia. Jurnal Dialog Penanggulangan Bencana, 4(2), 69-76. https://perpustakaan.bnpb.go.id/jurnal/index.php/JDPB/article/view/66 